\title{
Analisis Tingkat Kemampuan Literasi Media Petani Perkebunan di Provinsi Riau
}

\author{
Roza Yulida*, Rosnita, Eri Sayamar, Yulia Andriani \\ Jurusan Agribisnis, Fakultas Pertanian, Universitas Riau \\ * rozayulida@gmail.com
}

\begin{abstract}
Abstrak. Provinsi Riau memiliki potensi besar pada sektor perkebunan. Dua komoditi yang menjadi andalan adalah kelapa sawit dan keret, dengan pelaku utama dan paling banyak adalah petani swadaya. Salah satu kemampuan petani yang diperlukan saat ini dengan memanfaatkan perkembangan teknologi informasi dan komunikasi adalah kemampuan literasi media. Literasi media merupakan kemampuan petani memanfaatkan teknologi informasi untuk mencari atau mengakses melalui internet, memahami, memanfaatkan informasi dalam usahatani dan mengkomunikasikan informasi tersebut. Tujuan penelitian ini adalah menganalisis tingkat literasi petani pekebun di Provinisi Riau. Penelitian dilakukan di empat kabupaten di Provinisi Riau, dengan jumlah petani responden 240 orang petani. Hasil penelitian menunjukkan bahwa tingkat literasi petani berada pada level basic (skor 2,61), yang dikaji dari tiga aspek yaitu (1) aspek technical skill dengan skor 1,64 pada kategori basic; (2) Aspek critical understanding dengan skor 1,66 masuk pada kategori medium; dan (3) Aspek communication abilities pada kategori basic dengan skor 1,54. Hal ini menggambarkan bahwa masih rendahnya kemampuan petani baik petani kelapa sawit maupun karet dalam memanfaatkan teknologi informasi dan komunikasi seperti handphone (HP) atau smartphone yang mereka miliki untuk kebutuhan usahataninya. Peran penyuluh sangat diperlukan untuk meningkatkan litersi media petani pekebun, sehingga petani dapat memanfaatkan teknologi informasi dan komunikasi dalam mengembangkan usahataninya.
\end{abstract}

Kata Kunci: literasi media, petani swadaya

\section{PENDAHULUAN}

Komoditi kelapa sawit dan karet merupakan dua komoditi unggulan pada sektor perkebunan di Provinsi Riau. Bahkan Provinsi Riau merupakan salah satu provinsi di Indonesia sebagai penghasil utama untuk kedua komoditi ini. Pada tahun 2016 kelapa sawit dengan luas 2.012.951 ha, dengan produksi 7.668.681 ton dan jumlah petani $341.805 \mathrm{KK}$, dan merupakan kelapa sawit terluas dan produksi tertinggi di Indonesia (Direktorat Jenderal Perkebunan, 2017) .

Karet merupakan komoditas primodona kedua setelah kelapa sawit di Provinsi Riau. Menurut Direktorat Jenderal Perkebunan (2016) untuk komoditi karet dari Provinsi Riau pada tahun 2016 tercatat dengan luas 349.675 ha, jumlah produksi 324.143 ton yang diusahakan oleh petani karet sebanyak 18.135 petani karet. Potensi ini merupakan peringkat ketiga di Indonesia setelah Provinsi Sumatera Selatan dan Provinsi Sumatera Utara.

Potensi perkebunan yang besar peru diikuti oleh perkembangan sumberdaya petaninya. Supaya produksi perkebunan tersebut dapat bersaing dan berkembang. Salah satu aspek yang akan menentukan adalah kemampuan literasi media petani. Literasi media merupakan kemampuan petani untuk menggunakan perangkat (media) teknologi informasi dan komunikasi, kemampuan untuk mencari memanfaatkan teknologi informasi dan komunikasi tersebut untuk kepentingan dan pengembangan usahatani dan kemampuan petani untuk mengkomunikasi informasi tersebut melalui penggunaan teknologi media informasi dan komunikasi. Hal ini akan sangat berperan bagi petani untuk mengikuti perkembangan teknologi usahatani yang begitu cepat berkembang. Petani yang mampu memanfaatkan teknologi informasi seperti penggunaan smartphone atau media internet untuk mencari informasi dan menggunakannya dalam kegiatan usahatani, tentu akan berbeda dengan petani yang tidak memiliki kemampuan untuk itu.

Hasil penelitian yang dilakukan di Kabupaten Kuantan Singingi terhadap usahatani padi sawah menunjukkan bahwa tingkat kemampuan literasi media petani dilihat dari Individual competences berada

To cite this article: Yulida, R., Rosnita., E. Sayamar., dan Y. Andriani. 2019. Analisis Tingkat Kemampuan Literasi Media Petani Perkebunan di Provinsi Riau. Unri Conference Series: Agriculture and Food Security 1: 173-181.

https://doi.org/10.31258/unricsagr.1a23 
pada level basic dan tingkat kemampuan literasi media penyuluh berada pada level medium. Hal ini menunjukkan bahwa kemampuan literasi media petani pada kategori kurang mampu dan penyuluh pada kategori cukup mampu memanfaatkan kemajuan tekhnologi media yang berkembang saat ini (Yulida, 2017).

Kemampuan literasi media petani dapat menjadi gambaran bagaimana kemampuan petani dalam mengikuti perkembangan teknologi informasi dan komunikasi, terutama kemampuan memanfaatkan media dalam kaitannya mencari dan memanfaatkan informasi usahtani kelapa sawit atau karet. Oleh karena itu tujuan dari penelitian ini adalah untuk mengkaji tingkat literasi media petani di Provinsi Riau.

\section{METODE}

\section{Jenis dan Penentuan Lokasi Penelitian}

Penelitian menggunakan metode Survei, yang merupakan jenis penelitian dengan menggunakan kuesioner sebagai instrumen pengumpulan data. Pemilihan lokasi dilakukan secara Multi Stage Sampling yakni daerah yang memiliki luas perkebunan karet dan sawit terluas dan petani kelapa sawit dan karet yang aktif dalam kegiatan penyuluhaan. Dari empat kabupaten tersebut dua kabupaten dominan pengembangan komoditi perkebunan kelapa sawit yakni Kabupaten Pelalawan dan Rokan Hilir, dan dua kabupaten dalam pengembangan Karet yakni Kabupaten Rokan Hulu dan Kuantan Singingi. Disamping itu jumlah kelompoktani terbanyak pada 4 kabupaten terpilih.

\section{Metode Penentuan Responden}

Responden dalam penelitian ini adalah petani kelapa sawit pola swadaya dari Kabupaten Pelalawan dan Kabupaten Rokan Hilir dan petani karet dari Kabupaten Kuantan Singingi dan Kabupaten Kampar. Masingmasing kabupten ditentukan responden secara simpel random sampling sebanyak 60 orang petani, sehingga totol keseluruhan responden adalah 240 respon. Selain itu untuk memperdalam informasi dan analisis data juga dilakukan wawancara terhadap key informan yang terkait pada masing-masing kabupaten.

\section{Analisis Data}

Tingkat kemampuan literasi media penyuluh dan petani diikategorikan menggunakan Likerts Summated Rating Scale (LSRS) dimana setiap pilihan jawaban-jawaban diberi skor. Dimana masing-masing kategori dilihat dari tiga kriteria yaitu Technical Skills, Critical Understanding dan Communicative Abilities.

\section{HASIL DAN PEMBAHASAN}

\section{Karakteristik Internal dan Eksternal Petani Responden}

\section{Karakteristik Internal Petani}

Responden dari penelitian ini adalah petani kelapa sawit dan petani karet (petani pekebun) dari empat kabupaten di Provinsi Riau yang tergabung didalam kelompok tani, yang berjumlah 240 orang petani. Karakteristik petani diperlukan untuk melihat beberapa hal yang menjadi dasar pertimbangan dalam menggambarkan keadaan petani responden. Karakteristik tersebut dapat dilihat dari umur, tingkat pendidikan, pengalaman berusahatani dan tingkat kekosmopolitan petani.

\section{Umur Petani Responden}

Umur produktif merupakan umur pada kondisi manusia mampu melakukan kegiatan yang dapat menghasilkan pendapatan atau menghasilkan sesuatu yang dapat memenuhi kebutuhan hidupnya dan keluarga. Karena pada usia produktif manusia memiliki kemampuan fisik yang cukup untuk melakukan kegiatan-kegiatan yang bersifat poduktif. Usahatani merupakan kegiatan yang memerlukan kekuatan fisik untuk dapat melakukan aktivitas budidaya pertanian. Sehingga petani pada usia produktif tentu saja dapat melakukan kegiatan usahatani dengan baik. Data berikut memperlihatkan identitas responden berdasarkan tingkat umur yang disajikan pada Tabel 1 .

Tabel 1. Distribusi umur responden

\begin{tabular}{llcc}
\hline No & Umur & Jumlah (Jiwa) & Persentase (\%) \\
\hline 1 & Produktif & 204 & 85 \\
2 & Non Produktif & 36 & 15 \\
\hline & Jumlah & 240 & 100 \\
\hline
\end{tabular}


Berdasarkan Tabel 1 diketahui bahwa distribusi umur petani responden yang berada pada usia produktif (umur 15-55 tahun), yaitu sebanyak 204 jiwa atau sebesar 85\%. Kelompok ini merupakan potensi sebagai tenaga kerja produktif. Penduduk pada usia ini umumnya dapat lebih mudah mengadopsi dan merespon halhal baru (inovasi) yang dapat membangun dan mengembangkan usaha ekonomi yang sedang dijalankan sehingga berdampak positif terhadap pendapatan yang dapat meningkatkan kesejahteraan keluarganya. Sedangkan distribusi umur yang berada pada usia non produktif (umur $<15$ dan $>55$ tahun) sebanyak 36 jiwa atau sebesar $15 \%$.

Tingkat Pendidikan

Tingkat pendidikan ikut menentukan kualitas sumberdaya manusia. Semakin tinggi tingkat pendidikan, kecenderungannya akan semakin baik kualitas sumberdaya manusianya. Hal ini terkait dengan kemampuan seseorang dalam menyerap dan mengolah informasi yang didapat. Sehingga tingkat pendidikan yang tinggi diharapkan juga kemampuan berfikir dan bertindak yang lebih baik. Data berikut memperlihatkan identitas responden berdasarkan tingkat pendidikan yang disajikan pada Tabel 2.

Tabel 2. Tingkat pendidikan responden

\begin{tabular}{clccc}
\hline No & & Pendidikan & Jumlah (Jiwa) & Persentase (\%) \\
\hline 1 & SD & & 66 & 27 \\
2 & SMP & & 83 & 35 \\
3 & SMA & & 88 & 37 \\
4 & S1 & & 3 & 1 \\
\hline & & Jumlah & 240 & 100 \\
\hline
\end{tabular}

Berdasarkan Tabel 2 dapat dilihat bahwa tingkat pendidikan responden yang didominasi oleh tingkat pendidikan tamatan SMP dan tamatan SMA menunjukkan bahwa petani responden masih cukup mampu menjalankan aktivitas usahatani kelapa sawit atau karet dengan baik. Karena tingkat pendidikan akan mempengaruhi kemampuan petani responden dalam melakukan aktivitas usahatani dan adopsi terhadap teknologi baru.

\section{Luas Kepemilikan Lahan}

Luas kepemilikan lahan menjadi salah satu indikator status sosial di masyarakat. Petani dengan luas lahan yang lebih besar, kecenderungannya tingkat kehidupan dan status sosial dengan lebih baik juga. Lahan yang luas juga akan mampu menghasilkan pendapatan yang lebih besar, dan akan mempengaruhi kemampuan petani untuk mengambil keputusan dan keberanian petani dalam mengambil resiko. Petani yang lahannya sempit, pada umumnya kurang berani dalam mengambil keputusan yang mengandung resiko, sehingga juga akan lambat dalam melakukan perubahan-perubahan usahatani. Oleh karena itu luas lahan akan mempengaruhi kemampuan petani. Data berikut memperlihatkan identitas responden berdasarkan luas lahan pertanian yang disajikan pada Tabel 3 .

Tabel 3. Distribusi responden berdasar luas kepemilikan lahan

\begin{tabular}{clcc}
\hline No & \multicolumn{1}{c}{ Luas lahan (Ha) } & Jumlah (jiwa) & Persentase \\
\hline 1 & Petani Lahan Luas $>4$ & 14 & 6 \\
2 & Petani Lahan Sedang (>2-4) & 23 & 19 \\
3 & Petani Lahan Sempit (1-2) & 203 & 85 \\
\hline & Jumlah & 240 & 100 \\
\hline
\end{tabular}

Berdasarkan Tabel 3 dapat diketahui bahwa distribusi responden berdasarkan luas kepemilikan lahan paling banyak, berada pada petani lahan sempit (< 1-2 ha) sebanyak 203 petani atau $85 \%$, kemudian distribusi responden berdasar luas kepemilikan lahan kedua terbanyak berada pada petani lahan luas sedang (>2 - 4 ha) sebanyak 23 jiwa atau 19\%, dan untuk distribusi responden berdasar luas kepemilikan lahan luaas (>4 ha) sebanyak 14 jiwa atau 6\%.Hal ini dapat disimpulkan bahwa sebagian besar luas kepemilikan lahan petani kelapa sawit di lokasi penelitian memiliki lahan dengan kategori sempit.

Pengalaman Usahatani

Pengalaman usahatanin merupakan ilmu pengetahuan dan keterampilan sangat berpengaruh pada kemampuan dan keberhasilan petani. Walaupun pendidikan non formal juga mempengaruhi kemampuan petani, namun petani dengan pengalaman usahatani yang lebih lama, biasanya memiliki motivasi usahatani 
yang lebih baik dan lebih mudah dalam menyerap ilmu pengetahuan dan teknologi yang terkait dengan usahatani yang sedang dilakukan. Data berikut memperlihatkan identitas responden berdasarkan pengalaman berusahatani yang disajikan pada Tabel 4.

Tabel 4. Distribusi pengalaman usahatani petani

\begin{tabular}{ccccc}
\hline No & & Lama Usahatani (tahun) & Jumlah (jiwa) & Persentase \\
\hline 1 & 0 s/d 10 & 7 & 2 \\
2 & $>10$ s/d 20 & & 74 & 30 \\
3 & $>20$ & Jumlah & 163 & 68 \\
\hline & & 240 & 100 \\
\hline
\end{tabular}

Data yang didapat menunjukkan bahwa petani di lokasi penelitian memiliki pengalaman yang cukup lama dalam melakukan usahatani (68\% dengan pengalaman usahatahani $>20$ tahun). Petani yang memiliki pengalaman lebih lama berusahatani akan lebih tanggap dan peka dalam mengatasi masalah-masalah yang dihadapinya dan tahu apa cara yang baik untuk mengelolah usahataninya. Sedangkan petani yang pengalamannya $<5$ tahun, umumnya kurang tanggap dalam mengatasi masalah-masalah yang dihadapinya.

Kekosmopolitan

Sumardjo (2010) mengatakan rendahnya tingkat kekosmopolitan atau kemampuan petani untuk membuka diri terhadap suatu pembaharuan dan informasi yang berkaitan dengan unsur pembaharuan juga semakin memperburuk kondisi petani dalam membuat keputusan.Petani yang aktif untuk bergerak mencari informasi yang dapat mendukung usahatani yang dilaksanakan, akan menjadi pelopor (pioneer) bagi anggota kelompok dan masyarakat disekitarnya. Kemampuan bergaul dan menyerap informasi yang baik akan membantu petani mencari solusi atas kendala-kendala yang mereka hadapi. Data berikut memperlihatkan identitas responden berdasarkan kekosmopolitan yang disajikan pada Tabel 5 .

Tabel 5. Kekosmopolitan petani

\begin{tabular}{clcc}
\hline No. & \multicolumn{1}{c}{ Uraian } & Skor & Kategori \\
\hline 1. & $\begin{array}{l}\text { Petani membaca informasi pengetahuan tentang } \\
\text { budidaya tanaman kelapa sawit melalui media massa }\end{array}$ & 1,84 & Sedang \\
2. $\begin{array}{l}\text { Petani bergaul dengan petani lain untuk mencari } \\
\text { informasi pengetahuan tentang budidaya tanaman } \\
\text { kelapa sawit }\end{array}$ & 2,16 & Sedang \\
$\begin{array}{l}\text { Petani berpergian ke suatu tempat untuk mencari } \\
\text { informasi pengetahuan tentang budidaya tanaman } \\
\text { kelapa sawit }\end{array}$ & 1,84 & Sedang \\
\hline \multicolumn{2}{c}{ Jumlah Skor } & 5,84 & Sedang \\
\hline
\end{tabular}

Berdasarkan Tabel 5, kekosmopolitan petani kelapa sawit dan karet di Provinsi Riau termasuk kategori sedang dengan rata-rata skor 1,95. Hal ini menunjukkan petani termasuk cukup aktif untuk bergaul dan mencari informasi pengetahuan tentang budidaya tanaman kelapa sawit baik itu menggunakan media massa maupun dari petani lain serta ke suatu tempat yang dianggap memiliki informasi pengetahuan tambahan. Petani yang kosmopolit akan selalu mencari informasi pengetahuan berupa pengalaman melihat, mendengar, membaca (media massa, mediacetak maupun media elektronik), bergaul dengan sesamanya maupun berpergian kesuatu tempat sehingga dapat menambah pengetahuan atau pengalaman dalam memecahkan masalah dan perubahan perilaku pribadinya. Petani rata-rata melakukan kunjungan ke kelompok lain untuk mencari informasi paling sedikit 1 sampai 2 kali dalam sebulan. Interaksi dapat berupa diskusi langsung maupun bincang-bincang di warung kopi. Hal ini menunjukkan bahwa tingkat motivasi petani untuk mencari informasi pengetahuan tentang budidaya tanaman kelapa sawit atau karet cukup baik.

\section{Karakteristik Eksternal}

Karakteristik eksternal merupakan kondisi di luar rumah tangga petani yang mendukung kemampuan penggunaan teknologi informasi dan komunikasi petani.

Intensitas Penyuluhan 
Penyuluh pertanian lapangan adalah agen perubahan yang secara langsung berhubungan dengan petani. Fungsi utama penyuluh adalah mengubah perilaku petani melalui pendidikan non-formal sehingga petani memiliki kehidupan yang lebih baik secara berkelanjutan. Intensitas penyuluhan dalam hal ini adalah bagaimana peran nyata keberadaan penyuluh berdampak positif bagi petani. Seberapa sering penyuluh mengunjungi petani menjadi penting untuk menyelesaikan kendala yang mereka hadapi nantinya. Data berikut memperlihatkan identitas responden berdasarkan intensitas penyuluhan pertanian yang disajikan pada Tabel 6.

Tabel 6. Intensitas penyuluhan

\begin{tabular}{crcc}
\hline No. & Uraian & Skor & Kategori \\
\hline 1. & Penyuluh melakukan penyuluhan & 2,22 & Sedang \\
2. & Kecukupan intensitas penyuluhan & 2,21 & Sedang \\
\hline & Jumlah Skor & 4,43 & \multirow{2}{*}{ Sedang } \\
\hline
\end{tabular}

Berdasarkan Tabel 6, intensitas penyuluhan pertanian dikategorikan telah melaksanakan perannya dengan cukup baik. Intensitas penyuluhan termasuk kedalam kategori sedang dengan skor 2,22. Hal tersebut disebabkan frekuensi penyuluh dalam memberikan penyuluhan tentang budiaya tanaman kelapa sawit atau keret yang cukup yaitu rata-rata 2 kali dalam setahun, dengan intensitas 1 kali dalam 6 bulan melakukan penyuluhan.

Ketepatan Saluran Penyuluhan

Saluran penyuluhan dapat berupa komunikasi antara petani dan penyuluh secara langsung atau memanfaatkan alat bantu seperti media massa dalam kegiatan penyuluhan. Saluran penyuluhan yang baik akan memudahkan petani menyerap informasi dan ilmu yang disampaikan oleh penyuluh itu sendiri nantinya. Data berikut memperlihatkan identitas responden berdasarkan ketepatan saluran penyuluhan pertanian yang disajikan pada Tabel 7.

Tabel 7. Ketepatan saluran penyuluhan petani responden

\begin{tabular}{cccc}
\hline No. & Uraian & Skor & Kategori \\
\hline 1. & Saluran komunikasi dengandipraktekan penyuluh secara langsung & 2,35 & Sedang \\
2. & Saluran komunikasi melalui media massa & 2,09 & Sedang \\
\hline & Jumlah Skor & 4,44 & \multirow{2}{*}{ Sedang } \\
\hline
\end{tabular}

Berdasarkan Tabel 7, ketepatan saluran penyuluhan termasuk dalam kategori sedang dengan skor rata-rata 2,22. Kondisi ini menunjukan bahwa petani kelapa sawit atau petani karet di Provinsi Riau tergolong cukup mudah mendapatkan informasi tentang penyuluhan kelapa sawit atau karet dari penyuluh apabila kegiatan penyuluhan dilakukan secara langsung. Salah satu contoh yaitu penyuluhan menggunakan media penyuluhan audio visual berupa slide dan video tutorial. Petani beranggapan bahwa media penyuluhan ini akan lebih menyenangkan dan lebih gampang dipahami karena materi yang disajikan disertai gambar dan suara yang menarik.

Jumlah Sumber Informasi

Menurut Tondok (2013), individu atau kelompok yang memiliki jaringan informasi lebih luas akan lebih mudah memperoleh informasi sehingga mempunyai modal sosial yang tinggi dan mempunyai peluang untuk melakukan adopsi teknologi. Banyaknya jumlah informasi yang bermanfaat bagi petani akan membantu petani menghadapi tantangan dan kendala dalam melaksanakan budidaya tanaman kelapa sawit didalam kehidupannya. Kemudahan mendapatkan informasi terbaru juga akan membuat daya kreatif petani meningkat.

Tabel 8. Jumlah sumber informasi pengetahuan budidaya tanaman kelapa sawit dan karet di Provinsi Riau

\begin{tabular}{clcc}
\hline No. & \multicolumn{1}{c}{ Uraian } & Skor & Kategori \\
\hline 1. & $\begin{array}{l}\text { Jumlah informasi tentang budidaya tanaman } \\
\text { kelapa sawit }\end{array}$ & 2,18 & Sedang \\
2. & $\begin{array}{l}\text { Jumlah sumber informasi tentang budidaya } \\
\text { tanaman kelapa sawit }\end{array}$ & 1,96 & Sedang \\
\hline
\end{tabular}




\begin{tabular}{ccc}
\hline Jumlah Skor & 4,44 & \multirow{2}{*}{ Sedang } \\
\hline Rata-rata Skor & 2,07 & \\
\hline
\end{tabular}

Berdasarkan Tabel 8, jumlah sumber informasi yang diperoleh petani kelapa sawit terhadap budidaya tanaman kelapa sawit atau karet termasuk kategori sedang dengan rata-rata skor 2,07. Hal ini ditunjukan dengan jumlah informasi terbaru tentang budidaya tanaman kelapa sawit atau karet yang diterima petani ratarata sebanyak 3 informasi. Informasi yang didapatkan petani berupa materi yang berkaitan dengan pupuk, pestisida serta harga.

Untuk jumlah sumber informasi, ada terdapat 3 pihak utama maupun alat yang menjadi sumber informasi seputar budidaya tanaman kelapa sawit atau karet bagi para petani kelapa sawit atau petani karet di Provinsi Riau. Sumber informasi yang paling dominan didapat petani kelapa sawit atau karet berasal dari petani lain. Hal ini biasanya petani lakukan dengan cara bincang-bincang atau diskusi secara langsung dengan petani lainnya. Sumber informasi lain yang petani dapatkan berasal dari penyuluh serta toke yang kebanyakan didasari hubungan patron-klien.

\section{Keterjangkauan Mengakses Sumber Informasi}

Pada dasarnya ketersediaan informasi merupakan sumberdaya yang penting dalam pertanian.Ketersediaan informasi memegang peranan penting dalam membuka wawasan berpikir petani terhadap dunia nyata yang dialaminya.Sejumlah informasi yang diterima petani akan mengubah konsep-konsep yang ada dalam diri petani tersebut, kemudian membentuk suatu konsep baru yang merupakan penyesuaian informasi lama dengan sejumlah informasi baru yang diterima petani tersebut. Tuntutan kondisi seperti ini membangkitkan motivasi petani untuk mencari ide-ide baru dalam praktek pertaniannya yang akhirnya membuat petani tersebut menjadi lebih dinamis.

Tabel 9. Keterjangkauan mengakses sumber informasi menurut petani di Provinsi Riau

\begin{tabular}{cccc}
\hline No. & Uraian & Skor & Kategori \\
\hline 1. & Keterjangkauan tempat sumber informasi & 1,96 & Sedang \\
2. & Keterjangkauan jaringan internet dan sinyal & 2,62 & Sedang \\
\hline & Jumlah Skor & 4,58 & - \\
\hline & Rata-rata Skor & 2,29 & Sedang \\
\hline
\end{tabular}

Berdasarkan tabel 9 keterjangkauan mengakses sumber informasi menurut petani kelapa sawit atau karet di Provinsi Riau dikategorikan sedang dengan rata-rata skor 2,29. Hal tersebut dikarenakan keterjangkauan tempat kegiatan penyuluhan yang jauh > 200 meter dari rumah petani meskipun adanya kendaraan motor yang mempermudah menuju tempat informasi tersebut. Rendahnya keterjangkauan petani dalam mengakses tempat sumber informasi dapat menyebabkan petani malas untuk ketempat tersebut, sehingga menghambat motivasi petani untuk mencari ide-ide baru dalam praktek pertaniannya yang akhirnya membuat petani tersebut menjadi tidak dinamis.

Keterjangkauan jaringan internet dan sinyal yang tinggi memudahkan petani dalam berkomunikasi seperti menelpon penyuluh ataupun sesama petani yang lain. Serta petani juga bisa dengan mudah mengakses internet seperti google, youtube, dan lain-lain untuk mencari informasi baru dalam kegiatan budidaya tanaman kelapa sawit atau karet. Sehingga dapat mengendalikan kendala yang dihadapi oleh petani, dan membuka wawasan berpikir petani akan mengubah konsep-konsep yang ada dalam diri petani tersebut, kemudian membentuk suatu konsep baru yang merupakan penyesuaian informasi lama dengan sejumlah informasi baru yang diterima petani tersebut.

Ketersediaan Sarana Penyedia Media

Ketersediaan sarana penyedia media merupakan kemudahan mengakses media, adanya toko penjualan media pada daerah tesebut. jika tersedia sarana penyedia media membuat petani mudah untuk memiliki media tersebut. ketersediaan sarana penyedia media menyangkut pada ketersediaan informasi, Sejumlah informasi yang diterima petani akan mengubah konsep-konsep yang ada dalam diri petani tersebut, kemudian membentuk suatu konsep baru yang merupakan penyesuaian informasi lama dengan sejumlah informasi baru yang diterima petani tersebut.

Tabel 10. Ketersediaan sarana penyedia media menurut petani di Provinsi Riau

\begin{tabular}{cccc} 
No. & Uraian & Skor & Kategori \\
\hline 1. & Ketersediaan toko yang menjual media & 2,41 & Tinggi
\end{tabular}




\begin{tabular}{ccc}
\hline Jumlah Skor & 2,41 & - \\
\hline Rata-rata Skor & 2,41 & Tinggi \\
\hline
\end{tabular}

Berdasarkan tabel 31 menurut petani ketersediaan sarana penyedia media di Provinsi Riau pada kategori tinggi dengan rata-rata skor 2,41. Toko yang menjual media seperti handphone, smartphone, komputer, laptop, kartu perdana, service media, dan aksesoris penunjang media tersedia mudah ditemukan tapi dalam jumlah yang terbatas. Hal itu dikarenakan pada daerah trans hanya tersedia toko yang menjual kartu perdana dan aksesoris penunjang media saja. Tetapi toko media yang lengkap berada pada pusat kota yaitu di Desa Sorek Satu.

\section{Daya Dukung Lingkungan}

Daya dukung lingkungan adalah sesuatu yang bersifat dinamis, dapat terdegradasi atau punahapabila tidak dilestarikan dan sebaliknya dapat ditingkatkan kemampuannya serta mendukung ketersediaan sumberdaya yang dibutuhkan.

Kondisi lingkungan yang baik akan mendukung kegiatan budiaya tanaman kelapa sawit atau karet yang dijalankan petani. Ketersediaan sumber daya yang diperlukan dalam proses pelaksanaan kegiatan akan membantu kegiatan baik dari hulu sampai hilir.

Tabel 11. Daya dukung lingkungan dalam budidaya tanaman kelapa sawit dan keret di Provinsi Riau

\begin{tabular}{cccc}
\hline No. & Uraian & Skor & Kategori \\
\hline 1. & Penggunaan media yang ada dilingkungan & 2,46 & Tinggi \\
2. & Ketersediaan fasilitas jaringan internet & 2,80 & Tinggi \\
\hline & Jumlah Skor & 5,26 & - \\
\hline & Rata-rata Skor & 2,63 & Tinggi \\
\hline
\end{tabular}

Berdasarkan tabel 11 daya dukung lingkungan dalam budidaya tanaman kelapa sawit atau karet di Provinsi Riau berada pada kategori tinggi dengan rata-rata skor 2,63. Daya dukung lingkungan memenuhi dua kriteria yaitusebagian besar petani di Provinsi Riau berkomunikasi dengan menggunakan handphone seperti menelpon dan sms saja, namun sebagian kecil petani mampu menggunakan media sosial untuk berkomunikasi seperti whatsapp, facebook, dan lainnya. Kondisi lingkungan didukung dengan memiliki fasilitas jaringan internet yang mendukung dan bagus.

Tabel 12. Rekapitulasi karakteristik eksternal petani kelapa sawit dan karet di Provinsi Riau

\begin{tabular}{clcc}
\hline No. & \multicolumn{1}{c}{ Uraian } & Skor & Kategori \\
\hline 1. & Intensitas Penyuluhan & 2,22 & Sedang \\
2. & Ketepatan saluran penyuluhan & 2,22 & Sedang \\
3. & Jumlah sumber informasi & 2,07 & Sedang \\
4. & Keterjangkauan mengakses sumber informasi & 2,29 & Sedang \\
5. & Ketersediaan saprodi & 2,42 & Tinggi \\
6. & Ketersediaan sarana penyedia media & 2,41 & Tinggi \\
7. & Daya dukung lingkungan & 2,63 & Tinggi \\
\hline \multicolumn{2}{r}{ Jumlah Skor } & 16,26 & - \\
\hline
\end{tabular}

Berdasarkan Tabel 12 karakteristik eksternal di Provinsi Riau termasuk kategori sedang dengan skor ratarata 2,32. Intensitas penyuluhan, ketepatan saluran penyuluhan, jumlah sumber informasi, dan keterjangkauan mengakses sumber informasi termasuk dalam kategori sedang. Ketersediaan saprodi dan sarana penyedia media informasi dan teknologi, serta daya dukung lingkungan di Provinsi Riau termasuk dalam kategori tinggi.

\section{Tingkat Kemampuan Literasi Media Petani di Provinsi Riau}

Tingkat kemampuan literasi media penyuluh dan petani yang ada di Kecamatan Bagan Sinembah baik kemampuan untuk menggunakan, memproduksi, menganalisis, dan mengkomunikasikan pesan melalui media yaitu dapat dilihat dengan Individual competences . Individual competences merupakan kemampuan seseorang dalam menggunakan dan memanfaatkan media. Individual competences memiliki tiga variabel dalam kemampuan menggunakan dan memanfaatkan media diantaranya Technical Skills, Critical Understanding, dan Communicative Abilities. 
Technical Skills, yaitu kemampuan teknik dalam menggunakan media. Critical Understanding, merupakan kemampuan kognitif dalam menggunakan media seperti kemampuan memahami, menganalisis, dan mengevaluasi konten media.Communicative abilities, yakni suatu kemampuan untuk membangun relasi sosial serta berpartisipasi dalam lingkungan masyarakat melalui media.

\section{Tingkat Kemampuan Literasi Media Petani}

Tingkat kemampuan literasi media petani dapat dilihat pada Tabel 13.

Tabel 13. Tingkat kemampuan literasi media petani responden

\begin{tabular}{llcc}
\hline No. & \multicolumn{1}{c}{ Individual competences } & Skor & Level \\
\hline 1. & Technical skills & 1,64 & Basic \\
2. & Critical understanding & 1,66 & Medium \\
3. & Communicative abilities & 1,54 & Basic \\
\hline \multicolumn{5}{r}{ Jumlah skor } & 4,84 & \\
\hline & Rata-rata skor & 1,61 & Basic
\end{tabular}

Berdasarkan Tabel 13 Tingkat kemampuan literasi media petani berada pada level basic dengan total ratarata skor 1,61. Hal ini menjelaskan bahwa pada tingkat kemampuan teknik dalam menggunakan media (Technical skills) dan kemampuan kognitif dalam menggunakan media seperti kemampuan memahami, menganalisis, dan mengevaluasi konten media (Critical understanding) petani sudah cukup baik . Tetapi untuk kemampuan untuk membangun relasi sosial serta berpartisipasi dalam lingkungan masyarakat melalui media (Communicative abilities) masih kurang dikarenakan masyarakat memanfatkan media dengan baik untuk membangun relasi sosial.

Tabel 14. Tingkat kemampuan literasi media petani pada aspek Technical skill

\begin{tabular}{llcc}
\hline \multicolumn{1}{c}{ No. } & \multicolumn{1}{c}{ Technical skill } & Skor & Level \\
\hline 1. & $\begin{array}{l}\text { Kemampuan menggunakan iternet dan } \\
\text { komputer }\end{array}$ & 1,59 & Basic \\
2. & Kemampuan menggunakan media secara aktif & 1,70 & Medium \\
\hline & $\quad$ Jumlah skor & 3,29 & Basic \\
\hline
\end{tabular}

Berdasarkan Tabel 14 tingkat kemampuan literasi media petani pada Technical Skills berada dalam level medium dengan skor rata-rata 1,66. Dilihat dari skor rata-rata per indikator pada Technical Skills yang sudah cukup baik, sebagian petani sebatas tahu dalam menggunakan komputer dan juga internet. Sebagian petani sudah bisa menghidupkan komputer, mengoprasikan $m s$ word dan juga mengerti dalam penggunaan internet seperti browsing menggunakan google dan juga menggunakan media sosial namun belum dalam kegiatan usahatani kelapa sawit atau karet.

Tabel 15. Tingkat kemampuan literasi media petani pada aspek Critical understanding

\begin{tabular}{llcr}
\hline No. & \multicolumn{1}{c}{ Critical understanding } & Skor & Level \\
\hline 1. & Memiliki pengetahuan tentang media dan regulasi & 1,70 & Medium \\
& media & & Medium \\
2. & Kemampuan memahami konten dan fungsi media & 1,80 & Basic \\
3. & Prilaku pengguna dalam menggunakan media & 1,50 & Medium \\
\hline & Jumlah skor & 5,00 & 1,66 \\
\hline
\end{tabular}

Berdasarkan Tabel 15 tingkat kemampuan literasi media petani kelapa sawit di Kecamatan Bagan Sinembah pada Critical Understanding berada dalam level medium dengan skor rata-rata 1,66. Hal ini menjelaskan bahwa kemampuan memahami konten dan fungsi media internet pada petani sudah cukup baik, serta memiliki pengetahuan tentang regulasi terhadap pengunaan media komunikasi. Sebagian besar petani sudah mengetahui peraturan-peaturan penggunaan media internet, tetapi prilaku petani dalam penggunaan media masih kurang karena petani lebih mengutamakan pekerjaan.

Berdasarkan Tabel 16 tingkat kemampuan literasi media petani pada aspek Communicative abilities berada dalam level basic dengan skor rata-rata 1,54. Hal ini menjelaskan bahwa kemampuan berkomunikasi 
dan membangun relasi sosial petani melalui media cukup rendah, karena petani rata-rata hanya menerima informasi saja.

Tabel 16. Tingkat kemampuan literasi media petani pada aspek Communicative abilities

\begin{tabular}{llcc}
\hline No. & \multicolumn{1}{c}{ Communicative abilities } & Skor & Level \\
\hline 1. & $\begin{array}{l}\text { Kemampuan berkomunikasi dan membangun relasi sosial } \\
\text { melalui media }\end{array}$ & 1,34 & Basic \\
2. & $\begin{array}{l}\text { Kemampuan berpartisipasi dengan masyarakat melalui } \\
\text { media }\end{array}$ & 1,64 & Basic \\
3. $\quad \begin{array}{l}\text { Kemampuan untuk memproduksi dan mengkreasikan } \\
\text { konten media }\end{array}$ & 1,64 & Basic \\
\hline$\quad$ Jumlah skor & 4,62 & Basic \\
\hline
\end{tabular}

Kemampuan petani dalam berpartisipasi dengan masyarakat melalui media sudah cukup baik, sebagian besar petani berpartisipasi melalui media sosial yang tergabung dalam grop watshap untuk berbagi informasi dalam usahatani kelapa sawit dan karet, juga untuk menjalin komunikasi sesama petani. Tetapi masih rendahnya kemampuan petani untuk memproduksi dan mengkreasikan konten media.

\section{KESIMPULAN}

1. Karakteristik internal petani dari aspek umur merupakan tenaga kerja yang produktif. Tingkat pendidikan sebagian besar petani mengecap pendidikan SMP dan SMA. Persentase pengalaman usahatani termasuk dalam kategori bepengalaman. Luas lahan terbesar yang dimiliki petani berada pada indikator lahan sempit dan sedang. Kekosmopolitan termasuk dalam kategori tinggi. Pada umumnya petani memiliki handphone sebagai media komunikasi. Karakteristik eksternal petani termasuk kategori tinggi. Intensitas penyuluhan, ketepatan saluran penyuluhan, dan jumlah sumber informasi. Keterjangkauan harga saprodi, ketersedian saprodi, dan daya dukung lingkungan termasuk dalam kategori tinggi.

2. Tingkat literasi media petani termasuk kategori basic (skor 2,61), yang dikaji dari tiga aspek yaitu (1) aspek technical skill dengan skor 1,64 pada kategori basic; (2) Aspek critical understanding dengan skor 1,66 masuk pada kategori medium; dan (3) Aspek communication abilities pada kategori basic dengan skor 1,54 .

Peran penyuluh sangat diperlukan untuk meningkatkan litersi media petani pekebun, sehingga petani dapat memanfaatkan teknologi informasi dan komunikasi dalam mengembangkan usahataninya.

\section{DAFTAR PUSTAKA}

Direktorat Jenderal Perkbunan. 2016. Statistik Perkebunan Indonesia 2015-2017 Karet. Jakarta.

Direktorat Jenderal Perkbunan. 2017. Statistik Perkebunan Indonesia 2016-2018 Kelapa Sawit. Jakarta.

Tondok, A.R., P. Mappigau, dan Kaimuddin. 2013. Pengaruh Motivasi, Modal Sosial dan Peran Model terhadap Adopsi Teknologi PTT Cabai di Kabupaten Maros. Program Pascasarjana Universitas Hasanuddin. Makassar.

Yulida. 2017. Analisis Literasi Media Terhadap Penyuluh dan Petani di Desa Tebing Tinggi Kecamatan Benai Kabupaten Kuantan Singingi. UNES Journal of Agriculture Scienties 1(1). 